JURNAL BASICEDU

Research \& Learning in Elementary Education

https://jbasic.org/index.php/basicedu

\title{
PENGARUH PENERAPAN MODEL PROBLEM BASED LEARNING (PBL) TERHADAP AKTIVITAS DAN HASIL BELAJAR SISWA PADA PEMBELAJARAN TEMATIK TERPADU DI KELAS V SEKOLAH DASAR
}

\author{
Ade Novianti ${ }^{1}$,Alwen Bentri ${ }^{2}$, Ahmad Zikri $^{3}$ \\ ${ }^{1,3}$ Mahasiswa, UniversitasNegeri Padang, Indonesia \\ ${ }^{2}$ Pembimbing 1, UniversitasNegeri Padang, Indonesia \\ Email : noviantiade22@gmail.com ${ }^{1}$, alwenbentri@ fip.unp.ac.id ${ }^{2}$, zikria79@yahoo.com $^{3}$
}

\begin{abstract}
Abstrak
Tujuan penelitian ini untuk melihat pengaruh aktivitas dan hasil belajar siswa yang diajar menggunakan model pembelajaran Problem Based Learning ( PBL) dan kativitas serta hasil belajar yang diajar menggunakan metode konvensional pada pembelajaran tematik terpadu kelas V SDN 01 Barulak dan SDN 04 Tanjung Alam di Kabupaten Tanah Datar. Jenis penelitian adalah quasi eksperimet. Populasinya adalah siswa kelas V yang terdiri dari 2 kelas dengan jumlah 40 orang. Pengambilan sampel dilakukan dengan purpose sampling. Data penelitian dikumpulkan menggunakan menggunakan tes kemampuan awal dan tes kemampuan akhir. Berdasarkan hasil uji hipotesis diperoleh temuan :terdapat pengaruh yang signifikan antara model pembelajaran Problem Based Learning( PBL) terhadap aktivitas siswa pada pembelajaran berdasarkan perhitungan uji t diperoleh nilai nilai signifikan 0,00 lebih kecil dari taraf nyata 0,05 .terdapat pengaruh yang signifikan antara model pembelajaran Problem Based Learning( PBL) terhadap hasil belajar siswa pada pembelajaran berdasarkan perhitungan uji t diperoleh nilai nilai signifikan 0,00 lebih kecil dari taraf nyata 0,05 pada pembelajaran tematik terpadu di kelas V SD. Hasil penghitungan pada tabel dengan menguji uji $\mathrm{F}$ diperoleh $\mathrm{F}_{\text {hitung }}$ sebesar 1,008. Sedangkan $\mathrm{F}_{\text {tabel }}$ yang diperoleh adalah 2,85. Dapat disimpulkan bahwa terdapat pengaruh model pembelajaran PBL terhadap aktivitas dan hasil belajar siswa pada pembelajaran Tematik Terpadu di Kelas V Sekolah Dasar.

Kata kunci: Model Pembelajaran Problem Based Learning, Aktivitas, Hasil Belajar Tematik Terpadu
\end{abstract}

@ Jurnal Basicedu Prodi PGSD FIP UPTT 2019

$\triangle$ Corresponding author :

Address : Air Tawar Padang

Email : sfiooc3435@gmail.com

ISSN 2580-3735 (Media Cetak)

Phone : 089531307164 ISSN 2580-1147 (Media Online) 
195 Pengaruh Penerapan Model Problem Based Learning (PBL) Terhadap Aktivitas Dan Hasil Belajar Siswa Pada Pembelajaran Tematik Terpadu Di Kelas V Sekolah Dasar-Ade Novianti, Alwen Bentri dan Ahmad Zikri

\section{PENDAHULUAN}

Kurikulum merupakan salah satu unsur yang memberikan kontribusi untuk mewujudkan proses berkembangnya kualitas potensi peserta didik. Kurikulum yang saat ini diberlakukan di Indonesia adalah kurikulum 2013. Dijelaskan dalam Modul Pelatihan Implementasi Kurikulum 2013 (2014: 2) bahwa Kurikulum 2013 dikembangkan berbasis pada kompetensi sangat diperlukan sebagai instrumen untuk mengarahkan peserta didik menjadi: (1) manusia berkualitas yang mampu dan proaktif menjawab tantangan zaman yang selalu berubah; (2) manusia terdidik yang beriman dan bertakwa kepada Tuhan Yang Maha Esa, berakhlak mulia, sehat, berilmu, cakap, kreatif, mandiri; dan (3) warga negara yang demokratis, bertanggung jawab.

Pembelajaran tematik di Sekolah Dasar bertujuan untuk memperbaiki dan meningkatkan kualitas pendidikan. Pembelajaran tematik terpadu merupakan suatu pendekatan pembelajaran yang menggunakan sebuah tema untuk memadukan beberapa konsep atau materi pelajaran yang dipelajari secara holistik. Kajian holistik artinya mengkaji suatu peristiwa atau fenomena dari berbagai bidang studi sekaligus untuk memahami fenomena tersebut dari berbagai sisi. Menurut (Rusman,2014) Pembelajaran tematik merupakan salah satu model dalam pembelajaran terpadu (integrated instruction) yang merupakan suatu sistem pembelajaran yang memungkinkan siswa, baik secara individual maupun kelompok, aktif menggali dan menemukan konsep serta prinsipprinsip keilmuan secara holistik, bermakna, dan autentik. sebuah tema atau topik.

Pada pembelajaran tematik terpadu pada kurikulum 2013 memuat materi Ilmu Pengetahuan Sosial. Muatan materi Ilmu Pengetahuan Sosial (IPS) memiliki peranan yang penting sama halnya dengan muatan materi lainnya pada tematik terpadu di Sekolah Dasar. Pada sekolah dasar materi IPS terdiri dari kemampuan memahami isu, fakta, konsep, dan generalisasi. Muatan IPS diajarkan dimulai dari pengenalan lingkungan dan masyarakat terdekat mulai dari kabupaten, provinsi, nasional, dan internasional ( Wahyu Putri Utami.I, 2017,p. 57).

Dalam proses pembelajarannya, pembelajaran tematik menggunakan pendekatan saintifik. Hal ini dimaksudkan untuk memberikan pemahaman kepada siswa dalam mengenal, memahami berbagai materi menggunakan pendekatan ilmiah. Oleh karena itu, kondisi pembelajaran yang diharapkan tercipta diarahkan untuk mendorong siswa dalam mencari tahu dari berbagai sumber observasi, bukan diberi tahu.

Jasdila, dkk. (2017:3) menyatakan salah satu masalah dalam pembelajaran di SD adalah kurangnya pemahaman guru terhadap model pembelajaran yang tepat dan bervariasi yang diterapkan dalam pembelajaran. Hal ini menyebabkan pembelajaran kurang menarik, materi kurang dipahami peserta didik, hasil belajar rendah, dan tidak bermakna bagi peserta didik. Masalah umum lainnya termasuk pendekatan pembelajaran yang digunakan dalam kurikulum, sistem evaluasi hasil belajar siswa, dan pelatihan guru untuk kurikulum (Hayati, Bentri, \& Rahmi, 2017).

Berdasarkan informasi yang diperoleh dari guru kelas V SDN Gugus I Kecamatan Tanjuang Baru Kabupaten Tanah Datar melalui observasi yang dilakukan pada tanggal 4 Februari 2019 sampai dengan tanggal 16 Februari 2019 dan wawancara dengan salah seorang guru bernama Ibu Agusniar yang mengajar di UPT SDN 01 Barulak pada tanggal 4 Februari 2019 mengatakan bahwa "Anak-anak ketika belajar yang sifatnya hafalan mereka terlihat pasif dan bosan termasuk salah satu mata pelajaran yang bersifat hafalan 

Siswa Pada Pembelajaran Tematik Terpadu Di Kelas V Sekolah Dasar-Ade Novianti, Alwen Bentri dan Ahmad Zikri

tersebut adalah muatan materi IPS ketika disuruh belajar mereka hanya membolak balikan buku cetak dan mendengarkan apa yang disampaikan guru tanpa banyak yang merespon dari semua semua isi kelas ini” kata Ibu Agusniar.

Sejalan dengan observasi yang dilakukan pada tanggal 4 Februari 2019, 5 Februari 2019, 12 Februari 2019 dan 14 Februari 2019 yaitu : (1) siswa mengeluhkan muatan materi IPS karena banyak hafalan,(2) siswa kurang tertarik dengan materi pembelajaran muatan materi IPS, (3) sada saat diskusi kelompok siswa kurang bekerjasama dalam berdiskusi, dan cenderung tugas kelompok hanya dibuat oleh sebagian siswa saja,sedangkan sebagian siswa lainnya hanya duduk diam menunggu tugas kelompok selesai di buat. Akibatnya fungsi diskusi kelompok sebagai wadah untuk saling belajar, bertukar pikiran dan memupuk kerjasama siswa kurang tecapai dengan baik, (4) pembelajaran yang aktif yaitu student centered belum terlaksana dengan semestinya, 5) peserta didik tidak mengerjakan tugas yang diberikan guru dengan maksimal.

Berdasarkan hal tersebut tentu aktivitas siswa dalam pembelajaran tidak maksimal dan akhirnya berdampak terhadap hasil belajar siswa yang masih banyak belum mencapai batas Kriteria Ketuntasan Minimal (KKM) yang ditetapkan yaitu 70.

Permasalahan di sekolah dasar tersebut sesuai dengan permasalahan yang diutarakan oleh Vaughn, dkk (2013) bahwa pada saat ini siswa sekolah dasar memiliki interpersonal skill yang rendah di antaranya kurang memiliki keberanian dalam menyampaikan gagasan, kurang memiliki tanggung jawab dalam menyelesaikan tugas kelompok, serta memiliki sikap disiplin yang rendah. Masalah tersebut dikarenakan pembelajaran yang diberikan lebih mengandalkan teks, diskusi kurang menantang, serta penyelesaian masalah yang literat.

Menelaah dari permasalahan siswa yang belum menunjukkan aktivitas dalam belajar, dan sulit dalam memahami materi dan konsep pembelajaran IPS, maka hal ini berdampak pada rendahnya hasil belajar siswa dan siswa cenderung pasif.

Banyak cara yang digunakan guru untuk mengatasi permasalahan tersebut. Salah satunya diperlukan berbagai macam variasi yang digunakan guru dalam mengajar. Menerapkan model-model pembelajaran yang tepat dapat digunakan guru. Salah satunya adalah pembelajaran tematik terpadu pada kurilum 2013 dengan menerapkan model Problem Based Learning $(P B L)$.

Nur Cahyo.R, dkk （2018 ） dalam penelitiannya tentang Upaya Meningkatkan hasil belajar IPS melalui model Problem Based Learning ( $P B L)$ berbantuan Audio Visual pada siswa kelas 4 SD dengan hasil penelitian Problem Based Learning (PBL) merupakan model yang efektif untuk pengajaran proses berpikir, pembelajaran ini membantu siswa untuk memproses informasi yang sudah jadi dalam benaknya dan menyusun pengetahuan mereka sendiri tentang dunia social dan sekitarnya. Dengan Problem Based Learning (PBL) siswa dilatih menyusun sendiri pengetahuannya, mengembangkan keterampilan memecahkan masalah.

Hal ini sejalan dengan penelitian yang dilakukan Alfianiawati.T, dkk ( 2019) tentang pengaruh penggunaan model Problem Based Learning $(P B L)$ terhadap hasil belajar siswa dalam pembelajaran IPS di Kelas V SD dengan hasil penelitian menunjukkan pembelajaran dengan menggunakan model PBL berpengaruh positif terhadap prestasi dan hasil belajar siswa . 
197 Pengaruh Penerapan Model Problem Based Learning (PBL) Terhadap Aktivitas Dan Hasil Belajar Siswa Pada Pembelajaran Tematik Terpadu Di Kelas V Sekolah Dasar-Ade Novianti, Alwen Bentri dan Ahmad Zikri

Menurut Tan, dalam Rusmono (2012: 229) "Pembelajaran Berbasis Masalah (Problem Based Learning) merupakan inovasi dalam pembelajaran karena dalam kemampuan berpikir siswa betulbetul dioptimalisasikan melalui proses kerja kelompok atau tim yang sistematis, sehingga siswa dapat memberdayakan masalah, menguji dan mengembangkan kemampuan berpikirnya secara berkesinambungan".

Selanjutnya menurut Hosnan (2014:295) "Model Problem Based Learning (PBL) adalah model pembelajaran dengan pendekatan pembelajaran siswa pada masalah autentik sehingga siswa dapat menyusun pengetahuannya sendiri, menumbuh kembangkan keterampilan yang lebih tinggi dan inquiry, memandirikan siswa dan meningkatkan kepercayaan diri sendiri”.

Senada Hosnan (dalam Trianto, 2011: 98) menyatakan penerapan metode PBL terdiri atas lima langkah utama dalam proses pembelajaran yaitu: 1) Orientasi siswa pada masalah, 2) Mengorganisasikan siswa untuk belajar, 3) Membimbing penyelidikan individual dan kelompok, 4) Mengembangkan dan menyajikan hasil karya, 5)Menganalisis dan mengevaluasi proses pemecahan masalah.

Berdasarkan penjelasan di atas, maka peneliti tertarik untuk meneliti pengaruh penggunaan Problem Based Learning (PBL) terhadap aktivitas dan hasil belajar siswa pada kurikulum 2013 di Sekolah Dasar dengan judul "Pengaruh Penerapan Model Problem Based Learning (PBL) Terhadap Aktivitas dan Hasil Belajar Siswa pada Pembelajaran Tematik Terpadu di Kelas V Sekolah Dasar".

\section{METODE}

Jenis penelitian ini adalah penelitian eksperimen dengan pendekatan penelitian kuantitatif. Menurut Sugiyono (2013: 107) metode penelitian eksperimen dapat diartikan sebagai metode penelitian yang digunakan untuk mencari pengaruh perlakuan tertentu terhadap yang lain dalam kondisi yang terkendalikan. Pendekatan yang digunakan adalah pendekatan kuantitatif ini digunakan untuk menjawab rumusan masalah penelitian tersebut. (Sugiyono, 2013: 50).

Rancangan atau desain quasi eksperimen yang akan digunakan pada penelitian ini adalah menurut Suryabrata (2011:104) yaitu "The Static Comparison: Randomized Control Group Only Desain”.. Pada desain ini peneliti menggunakan sekelompok subjek penelitian dari suatu populasi tertentu, kemudian dikelompokkan secara rasndom menjadi dua kelompok atau kelas, yaitu kelas eksperimen dan kelas kontrol. Pada kelas eksperimen diberikan perlakuan dengan menggunakan model PBL sedangkan pada kelas kontrol diberikan pembelajaran seperti biasa yaitu model pembelajaran konvensional.

Penelitian ini menggunakan probability sampling dengan teknik simpel random sampling. Menurut Sugiyono (2012:120) “Teknik simpel random sampling dalah pengambilan anggota sampel dari populasi dilakukan secara acak tanpa memperhatihan strata yang ada dalam populasi tersebut". Alasan peneliti menggunakan teknik simple random sampling untuk memudahkan pelaksanaan penelitian karena penyebaran siswa berada pada kelas yang memiliki karaktristik yang hampir sama atau homogen.

Peneliti terlebih dahulu melakukan observasi dan wawancara dengan guru kelas $\mathrm{V}$ SDN Gugus I Kecamatan Tanjung Baru pada tanggal 4 Februari 2019- 16 Februari 2019. Kemudian menentukan kelas untuk pengambilan sampel. Penelitian ini menggunakan dua kelas yang dijadikan sampel penelitian, yaitu kelas kontrol dan kelas eksperimen. 
198 Pengaruh Penerapan Model Problem Based Learning (PBL) Terhadap Aktivitas Dan Hasil Belajar Siswa Pada Pembelajaran Tematik Terpadu Di Kelas V Sekolah Dasar-Ade Novianti, Alwen Bentri dan Ahmad Zikri

Teknik pengumpulan data yang digunakan dalam penelitian ini adalah menggunakan tes hasil belajar. Tes hasil belajar yang digunakan berupa pretest dan postest. Pembuatan soal ini didasarkan pada kisi-kisi soal yang dibatasi untuk mengukur kemampuan C1 ( Pengetahuan),C2 ( pemahaman) dan C3 ( penerapan ). Setelah uji coba dilaksanakan, dilakukan uji analisis tes untuk melihat baik atau tidaknya suatu soal. Langkahlangkah uji analisis soal adalah dengan validitas item tes hasil belajar. Sebuah tes dikatakan valid apabila tes tersebut secara tepat dapat mengukur apa yang seharusnya diukur (Arikunto,2013:211). Dalam penelitian ini digunakan uji validitas empiris (empirical validity). Validitas empiris adalah validitas yang ditinjau dari kriteria tertentu. Kriteria ini digunakan untuk menentukan tinggi rendahnya koefisien validitas instrumen. Perhitungan validitas empiris ini menggunakan korlampelasi product-moment dengan rumus sebagai berikut.

$r_{x y}=\frac{n\left(\sum x y\right)\left(\sum x\right)\left(\sum y\right.}{\left.\sqrt{\left\{n\left(\sum x^{2}\right)-\left(\sum x\right)^{2}\right\}}\left\{n\left(\sum x^{2}\right)-\sum y\right)^{2}\right\}}$

Keterangan:

$\mathrm{r}_{\mathrm{xy}} \quad$ : koefisien korelasi

n : jumlah subjek/sampel yang diteliti

$\mathrm{x} \quad$ : skor item

y : skor total

Kriteria penilaian:

$\begin{array}{ll}0.80-1.00 & \text { : Sangat tinggi } \\ 0.60-0.80 & : \text { Tinggi } \\ 0.40-0.60 & \text { : Cukup } \\ 0.20-0.40 & \text { : Rendah } \\ 0.0-0.20 & \text { : Sangat rendah }\end{array}$

Hargar $r_{x y}$ yang diperoleh kemudian dikonsultasikan dengan $r_{\text {tabel.. }} \quad$ Uji reliabilitas dilakukan untuk mendapatkan tingkat ketepatan alat pengumpul data yang digunakan. Uji reliabilitas dilakukan pada soal-soal yang dikategorikan dipakai atau direvisi. Reliabilitas ini dihitung dengan menggunakan rumus Kude Richardson (KR 20). Adapun rumusnya adalah:

$$
r_{11}=\left(\frac{n}{n-1}\right)\left(1-\frac{\Sigma \sigma_{1}^{2}}{\sigma_{1}^{2}}\right)
$$

Dimana:

$\mathrm{r}_{11} \quad=$ Reliabilitas yang diberi

$\mathrm{n} \quad=$ Jumlah item

$\Sigma \sigma_{1}^{2}=$ Jumlah varians skor tiap-tiap item

$\Sigma_{t}^{2} \quad=$ Varian total

Kriteria reabilitas menurut Arikunto (2010:89) sebagai berikut:

$0,80<\mathrm{r}_{11} \leq 1,00$ : reliabilitas tinggi sekali

$0,60<r_{11} \leq 0,80$ : reliabilitas tinggi

$0,40<r_{11} \leq 0,60$ : reliabilitas cukup

$0,20<\mathrm{r}_{11} \leq 0,40$ : reliabilitas rendah

$0,00<r_{11} \leq 0,20:$ reliabilitas sangat rendah

Data persentase aktivitas siswa dihitung dengan menggunakan rumus yang dikemukakan oleh Sudjana (2010:130) yaitu :

$$
\mathrm{P} \%=\frac{F}{N} \times 100 \%
$$

Keterangan :

$$
\begin{array}{ll}
\mathrm{P} \% & =\text { Persentase aktivitas } \\
\mathrm{F} & =\text { Frekuensi aktivitas } \\
\mathrm{N} & =\text { Jumlah siswa }
\end{array}
$$

Setelah diperoleh persentase aktivitas siswa, selanjutnya akan dilihat kriteria aktifitas berdasarkan yang dikembangkan oleh Dimyati (2009:125):

Uji normalitas dilakukan untuk mengetahui normal atau tidaknya sebaran data yang dianalisis. Uji normalitas terhadap masing-masing kelompok data menggunakan uji Liliefors. Irianto (2004:272). Dengan menggunakan daftar distribusi normal baku dihitung peluang $F\left(z_{i}\right)=P\left(z \leq z_{i}\right)$ .Dimana data yang normal apabila $L_{\text {hitung }}<L_{\text {tabel }}$ dengan taraf signifikan $0,05(5 \%)$ dan begitupun sebaliknya apabila $L_{\text {hitung }}<L_{\text {tabel }}$ maka sebaran data tidak normal.

Uji homogenitas variansi dilakukan dengan menggunakan uji $\mathrm{F}$. Uji $\mathrm{F}$ ini dilakukan untuk 
199 Pengaruh Penerapan Model Problem Based Learning (PBL) Terhadap Aktivitas Dan Hasil Belajar Siswa Pada Pembelajaran Tematik Terpadu Di Kelas V Sekolah Dasar-Ade Novianti, Alwen Bentri dan Ahmad Zikri

mengetahui apakah kedua kelas mempunyai variansi yang homogen atau tidak.

Uji hipotesis yang akan digunakan dalam penelitian ini adalah uji t dalam Sudjana (2005: 239) dengan rumus sebagai berikut:

$$
\mathrm{t}=\frac{x_{i}-\bar{x}}{5 \sqrt{\frac{1}{n_{1}}+\frac{1}{n_{2}}}}
$$

Keterangan:

$$
\begin{array}{ll}
X i & =\text { Rata-rata kelompok eksperimen } \\
x \boldsymbol{x} & =\text { Rata-rata kelompokkontrol } \\
\mathrm{S} & =\text { Variansigabungan( simpangan baku } \\
& \text { kelompok data ) } \\
\mathrm{n}_{1} & =\text { Jumlahsampelkelompokkontrol } \\
\mathrm{n}_{2} & =\text { Jumlahsampelkelompok eksperimen }
\end{array}
$$

\section{HASIL DAN PEMBAHASAN}

Penelitian ini bertujuan untuk melihat aktivitas dan hasil belajar peserta didik yang diajar menggunakan model Problem Based Learning dan peserta didik yang diajar menggunakan pendekatan konvensional. Kegiatan penelitian ini dilaksanakan bulan September sampai November 2019 di kelas V SDN 01 Barulak dan SDN 04 Tanjung Alam.

Pengaruh model pembelajaran PBL terhadap aktivitas siswa pada pembelajaran tematik terpadu di kelas V SD.

Data aktivitas belajar diperoleh melalui lembar pengamatan. Secara keseluruhan data aktivitas belajar peserta didik mengungkapkan informasi tentang aktivitas peserta didik pada kelas eksperimen dan kelas kontrol serta skor tertinggi, skor terendah, dan rata-rata, yang dapat dilihat pada tabel 5 berikut ini :

Tabel 1. Aktivitas Peserta didik Kelas Eksperimen dan Kelas Kontrol

\begin{tabular}{|l|c|c|c|c|}
\hline \multicolumn{1}{|c|}{ Kelas } & $\mathrm{N}$ & $\bar{x}$ & $\mathrm{X} \min$ & $\mathrm{X} \max$ \\
\hline Eksperimen & 20 & 91,1 & 75 & 100 \\
\hline Kontrol & 20 & 80,4 & 70 & 97 \\
& & & & \\
\hline
\end{tabular}

Berdasarkantabel1dapatdilihat rata-rata aktivitaspesertadidikdalambelajarTematikTerpadu. Pada kelas eksperimen terdapat 20 peserta didik. Nilai tertinggi 100 dan terendah 75. Sedangkan pada kelas kontrol yang terdiri dari 20 orang peserta didik, nilai tertinggi 97 dan terendah 70 . Berdasarkan table di atas, peserta didik pada kelas eksperimen memiliki aktivitas yang lebih tinggi dibandingkan dengan peserta didik kelas kontrol. Secara keseluruhan, data aktivitas belajar dapat digambarkan sebagai berikut.

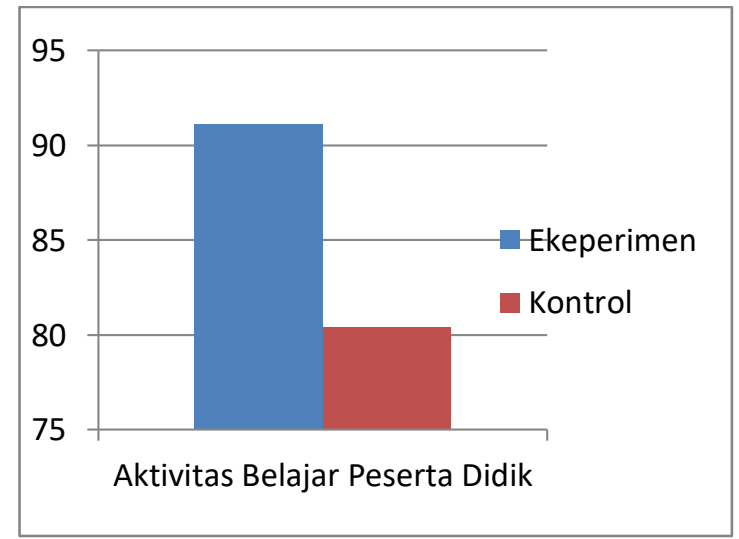

Gambar 1. Grafik Hasil Belajar Kelas Eksperimen Dan Kelas Kontrol

Pengaruh model pembelajaran PBL terhadap hasil belajar siswa pada pembelajaran tematik terpadu di kelas V SD

Data hasil belajar peserta didik diperoleh dari kognitif, afektif, dan psikomotor. Data hasil belajar ini diperoleh dari kelas eksperimen dan kelas kontrol. Hasil belajar kognitif diperoleh melalui tes tertulis berupa soal objektif sebanyak 30 pertanyaan. Hasil belajar afektif diperoleh dengan lembar penilaian sikap, dan aspek psikomotor dengan penilaian unjuk kerja.

Data hasil belajar peserta didik secara keseluruhan di kelas eksperimen dan kelas kontrol yang diperoleh dideskripsikan Tematik Terpadu menurut skor total, skor tertinggi, skor terendah, dan rata-rata masing kelas. Deskripsikan Tematik Terpadu data mengenai hasil belajar peserta didik disajikan dalam tabel 6 di bawah ini. 
200 Pengaruh Penerapan Model Problem Based Learning (PBL) Terhadap Aktivitas Dan Hasil Belajar Siswa Pada Pembelajaran Tematik Terpadu Di Kelas V Sekolah Dasar-Ade Novianti, Alwen Bentri dan Ahmad Zikri

Tabel 2. Rata-Rata Hasil Belajar Di Kelas Eksperimen dan Kontrol

\begin{tabular}{|l|c|c|c|c|}
\hline \multicolumn{1}{|c|}{ Kelas } & $\mathrm{N}$ & $\bar{x}$ & $\begin{array}{l}\mathrm{X} \\
\min \end{array}$ & $\mathrm{X}$ mak \\
\hline Eksperimen & 20 & 88,8 & 72 & 100 \\
\hline Kontrol & 20 & 80,6 & 68 & 92 \\
\hline
\end{tabular}

Keterangan :

$\mathrm{n} \quad$ : jumlah peserta didik

$\bar{x} \quad$ : nilai rata-rata

$\mathrm{X}_{\max }$ : nilai maksimum

$\mathrm{X}_{\min } \quad$ : nilai minimum

Dari hasil perhitungan tabel 2 , terlihat ratarata hasil belajar peserta didik kelas eksperimen lebih tinggi dari pada kelas kontrol. Hal itu terjadi karena peserta didik di kelas eksperimen mampu melatih kesiapan peserta didik dan saling memberikan pengetahuan dan melatih kesiapan peserta didik dalam menanggapi serta menyelesaikan masalah. Karena dalam model Problem Based Learning peserta didik dilatih untuk siap dan saling memberikan pengetahuan terhadap anggota kelompok. Hal ini berbeda dengan modelkonvensional yang menitikberatkan penyampaian pengetahuan oleh guru.

Secara keseluruhan data hasil belajar di kelas eksperimen dan kelas kontrol dapat digambarkan sebagai berikut.

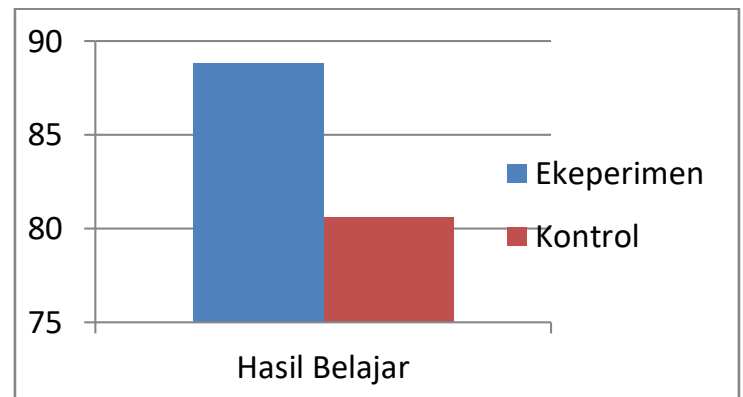

Gambar 2. Grafik Hasil Belajar Kelas Eksperimen Dan Kelas Kontrol

Hasil penelitian menunjukkan bahwa aktivitas belajar siswa yang diajar menggunakan model pembelajaran Problem Based Learning( $P B L)$ lebih baik daripada metode konvensional

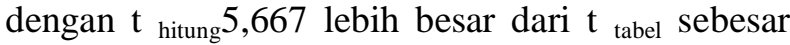
2,101 dengan taraf nyata $\alpha=0,05$. Hasil belajar siswa yang diajar menggunakan model pembelajaran Problem Based Learning( PBL) lebih baik daripada metode konvensional dengan $\mathrm{t}$ hitung 3,977 lebih besar dari $\mathrm{t}_{\text {tabel }}$ sebesar 2,101 dengan taraf nyata $\alpha=0,05$ Hasil penghitungan pada tabel dengan menguji uji $\mathrm{F}$ diperoleh $\mathrm{F}$ hitung sebesar 1,008. Sedangkan $\mathrm{F}$ tabel yang diperoleh adalah 2,85. Dapat disimpulkan bahwa terdapat pengaruh model pembelajaran PBL terhadap aktivitas dan hasil belajar siswa pada pembelajaran Tematik Terpadu di Kelas V Sekolah Dasar.

\section{SIMPULAN}

Hasil penelitian ini telah menjelaskan tentang pengaruh model Problem Based Learning $(P B L)$ terhadap aktivitas dan hasil belajar siswa pada pembelajaran tematik terpadu di kelas $\mathrm{V}$ Sekolah Dasar. Berdasarkan hasil uji hipotesis diperoleh temuan :terdapat pengaruh yang signifikan antara model pembelajaran PBL terhadap aktivitas siswa pada pembelajaran berdasarkan perhitungan uji t diperoleh nilai nilai signifikan 0,00 lebih kecil dari taraf nyata 0,05.terdapat pengaruh yang signifikan antara model pembelajaran PBL terhadap hasil belajar siswa pada pembelajaran berdasarkan perhitungan uji t diperoleh nilai nilai signifikan 0,00 lebih kecil dari taraf nyata 0,05 pada pembelajaran tematik terpadu di kelas V SD.

Berdasarkan temuan penelitian tersebut di atas dapat dikemukakan kesimpulan : Aktivitas dan hasil belajar siswa di Kelas V Sekolah Dasar dapat ditingkatkan dengan menerapkan model pembelajrajn Problem Based Learning (PBL).

\section{DAFTAR PUSTAKA}

Abdul Majid .(2013). Strategi Pembelajaran .Remaja Rosdakarya:Bandung.

Abidin, Yunus. (2014). Desain Sistem Pembelajaran dalam Konteks Kurikulum 2013. Bandung: Refika Aditama.

Ali, Mohammad. (2010). Metodologi dan Aplikasi 
201 Pengaruh Penerapan Model Problem Based Learning (PBL) Terhadap Aktivitas Dan Hasil Belajar Siswa Pada Pembelajaran Tematik Terpadu Di Kelas V Sekolah Dasar-Ade Novianti, Alwen Bentri dan Ahmad Zikri

\section{Riset Pendidikan. Bandung: Cendikia Utama}

Amir, M. Taufiq.(2009). Inovasi Pendidikan Melalui Problem Based Learning. Jakarta: Prenada Media Group.

Arikunto, Suharsimi.(2012). Prosedur Penelitian Suatu Pendekatan Praktik. Edisi Revisi V. Jakarta: Rineka Cipta.

Auliah Sumitro, dkk.(2017).Penerapan Model PBL Meningkatkan Motivasi dan Hasil Belajar IPS. Jurnal UM.Vol 2.No.9. 1-8.

Badan Pengembangan Sumber Daya Manusia Pendidikan dan Kebudayaan dan Penjamin Mutu Pendidikan. (2014). Modul Pelatihan Guru Implementasi Kurikulum 2013.Jakarta: Kemdikbud.

Djamarah, Syaiful Bahri.(2006). Psikologi Belajar, Jakarta: PT. Rineka Cipta.

Dimyati, Mudjino. (2009). Belajar dan Pembelajaran. Jakarta: Rineka Cipta Abbas.

Pembelajaran. Jakarta: PT Rineka Cipta

Fadillah, M.(2014). Implementasi Kurikulum 2013 dalam Pembelajaran SD/MI, SMP/MTs, \& SMA/MA. Yogyakarta: Ar-Ruzz Media.

Ginting, Kula. (2013). "Penerapan Model Pembelajaran Contextual Teaching And Learning Untuk Meningkatkan Aktivitas Dan Hasil Belajar IPS Siswa Kelas V SD Negeri 060885 Medan" Jurnal Universitas Terbuka ,Volume 003, Nomor 12,1-22.

Hamzah B. Uno. (2011). Teori Motivasi dan Pengukurannya: Analisis di Bidang Pendidikan. Jakarta: Bumi aksara

Hayati, A., Bentri, A., \& Rahmi, U.(2017). Analyzing the Issues in the Implementation of Authentic Assessment in the 2013 Curriculum. Al-Ta'lim Journal, 24(1), 53-59.

Irianto, Agus. (2004). Statistik Konsep Dasar Aplikasi dan Pengembangannya. Jakarta: Kencana.

Istarani.(2012).Model Pembelajaran Inovatif. Medan : Media Persada.

Ngalimun.(2014).Strategidan Pembelajaran.

Model AswajaPressindo.

Nuh, Muhammad. (2014). Pengembangan dan Implementasi Kurikulum 2013.Bandung: PT Remaja Rosda Karya.
Paul D. Dierich. (2013). Classroom Management for Secondary Teachers. Englewood Cliffs, New Jersey: Prentice Hall, Inc.

Paul Egendan Don Kauchak. (2013). Strategi dan Model Pembelajaran Mengajarkan Kontendan Keterampilan Berpikir, terjemahan Satriro Wahono .Jakarta: Indeks.

Rusmono. (2012). Startegi Pembelajaran dengan Problem Based Learning itu perlu: untuk meningkatkan profesionalisme guru. Bogor: Ghalia Indonesia.

Sitiatava Rizema Putra. (2013). Desain Belajar Mengajar Kreatif Berbasis SAINS Yogyakarta: Diva Press, hh.72-73.

Strohfeldt, Katja \& Olga Khutoryanskaya. (2015). Instructional Design And Assessment Using Problem-Based Learning in a Chemistry Practical Class for Pharmacy Students and Engaging Them with Feedback, American Journal of Pharmaceutical Education.

Sudjana. (2005). Metode Statistika Edisi ke-6. Bandung :Tarsito

Sudjana, Nana.(2010). Penilaian Hasil Proses Belajar Mengajat. Bandung: Remaja Rosdakarya.

Sugiyono. (2005). Metode Penelitian Bisnis (Pendekatan Kuantitatif, Kualitatif, dan $R \& D)$. Bandung: Alfabeta.

(2012). Metode Penelitian Pendekatan Kuantitatif, Kualitatif dan $R \& D$. Bandung: Alfabeta.

Sugiyono. (2013). Metodelogi Penelitian Kuantitatif, Kualitatif Dan R\&D. Bandung: Alfabeta.

Suprijono, Agus. (2009). Cooperative Learning Teori\&Aplikasi PAIKEM. Yogyakarta :Pustaka Pelajar.

Suryabrata, Sumadi.(2011). Psikologi Pendidikan, Jakarta: PT. Raja Grafindo Persada.

Syofian Siregar. (2014). Metode Penelitian Kuantitatif. Jakarta: Kencana

Syah Darwyan, dkk. (2009). Strategi Belajar Mengajar. Jakarta: Diadit Media.

Tan, Oon-seng. (2004). Enhancing Thingking Through Problem-Based Learning Approaches: international perspective. Singapore:Cengage learning.

Tia Alfianiawati,dkk. (2019). Pengaruh 
202 Pengaruh Penerapan Model Problem Based Learning (PBL) Terhadap Aktivitas Dan Hasil Belajar Siswa Pada Pembelajaran Tematik Terpadu Di Kelas V Sekolah Dasar-Ade Novianti, Alwen Bentri dan Ahmad Zikri

Penggunaan Model Problem Based Learning (PBL) Terhadap Hasil Belajar Siswa Dalam Pembelajaran IPS di Kelas V SD.e-Journal UNP. Vol 7. No 3. Hal 1-10.

Trianto. (2011). Mendesain Model Pembelajaran Inovatif-Progresif: Konsep, Landasan, dan Implementasinya pada Kurikulum Tingkat Satuan Pendidikan (KTSP) .Jakarta: Kencana Prenada Media Group.

(2011). Model-model Pembelajaran Inovatif Berorientasi Kontruktivis. Jakarta: Prestasi Putaka.

Wulandari,dkk. (2016). "Penerapan Model CTL Berbasis Karakter Untuk Meningkatkan Kemampuan Berpikir Kritis Pada Pembelajaran IPS', Antologi UPI, Nomor 4,1-18.

Yarnidan Bustari Muchtar. (2014). Pengaruh Model Pembelajaran Student Team Achievement Divisions (STAD) dan Motivasi Belajar Terhadap Hasil Belajar Akuntansi Siswa Kelas X Akuntansi 3 di SMKN 1 Payakumbuh. E-journal UNP.

Yuliana Septiana. (2012). Pendekatan Problem Based Learning (PBL) Untuk Meningkatkan Pemahaman Konsep Siswa Kelas IV SD Negeri Cigugur Girang Kecamatan Parongpong Kabupaten Bandung Barat. 